\title{
Durability Properties of Silivri Limestone and Usability in Stone Building Restorations
}

\author{
Murat Dal $^{1^{*}}$, Musa Tokmak ${ }^{2}$ \\ ${ }^{I}$ Munzur University, Department of Civil Engineering, Tunceli, Turkey \\ ${ }^{2}$ Middle East Technical University, Institute of Science, Department of Archeometry, Ankara, Turkey \\ *muratdal@munzur.edu.tr (iD), musatokmak3@yahoo.com $\mathrm{D}$ \\ Received date: 20.04.2020, Accepted date: 19.06.2020
}

\begin{abstract}
Istanbul-Bakırköy kufeki stone has been widely used as a building block in traditional architectural structures in Istanbul. The petrogaphic, physicomechanical and chemical properties of limestone, which was extracted from the quarries of Istanbul-Silivri-Akören village and used as building stone repair stone in traditional architectural buildings in Istanbul and contemporary architecture, are determined according to TS 699. According to the studies, Silivri stone is a limestone with high silica content. According to the results of the experiments, it was examined that kufeki stone could be used as a building block and that Bakırköy kufeki stone could fill the gap in the restoration of traditional buildings. Consequently, it is suitable to be used in the restoration works of historical works built with kufeki stone in terms of color and technical features kufeki stone in terms of color and technical features.
\end{abstract}

Keywords: Küfeki, Silivri limestones, technical properties of stone, traditional stone structures

\section{Silivri Kireçtaşının Durabilite Özellikleri ve Taş Yapı Restorasyonlarında Kullanılabilirliği}

$\ddot{\mathbf{O}} \mathbf{z}$

İstanbul-Bakırköy küfeki taşı İstanbul'daki geleneksel mimari yapılarda yapı taşı olarak yaygın olarak kullanılmıştır. İstanbul-Silivri-Akören köyü taş ocaklarından çıkarılan ve İstanbul'daki geleneksel mimari yapılarda yapı taşı onarımlarında ve çağdaş mimaride yapı taşı, kaplama taşı olarak kullanılan kireçtaşının petrogafik, fizikomekanik ve kimyasal özellikleri TS 699'a göre belirlenmiştir. Yapılan çalışmalara göre Silivri taşı silis içeriği yüksek bir kireçtaşıdır. Deneylerin sonuçlarına göre küfeki taşının yerine yapı taşı olarak kullanılabileceği ve geleneksel yapıların restorasyonlarında Bakırköy küfeki taşının boşluğunu doldurabileceği irdelemesi yapılmıştır. Sonuç olarak renk ve teknik özellikleri açısından, küfeki taşı ile inşa edilen tarihi eserlerin restorasyon çalışmalarında kullanılabilmesi uygundur.

Anahtar Kelimeler: Küfeki, Silivri kireçtaşları, taşın teknik özellikleri, geleneksel taş yapılar

\section{INTRODUCTION}

The oldest building material used in the architectural field throughout history is natural stones. Since it is an original, aesthetic, durable, healthy and sustainable material, it has been used in different forms in the past and today. Kufeki stones were widely used in different building types during the Ottoman, Byzantine and Roman periods. Especially during the Ottoman period, Mimar Sinan was frequently used in historical buildings in Thrace and Istanbul. Since the Bakırköy küfeki is under the settlement, new quarries were needed in the restoration of historical stone works. The stone wears down and the deterioration process begins on the historical stone structures with the reasons such as atmospheric conditions, air pollution, improper internal structure features, biological effects, saltacid effects, public works effects, faulty workmanship, negative human effects (Woolfitt, 2000; Fitzner and Heinrichs, 2004; Smith and Turkington, 2004). In the restoration of these stones, the stones closest to the old stone should be preferred. For this reason, all the technical properties of the stone to be used should be known. It is very important that the historical stone structures are restoredaccording to the original structured and they must be transferred to the next generations. 
Silivri limestone, which meets the building block requirement of Istanbul and Thrace Region, is a limestone formed by shells, mostly mussel shells. It is a compact rock with light beige, light yellow, dirty white shades, fine-gained and sandy appearance, abundant fossil, hollow, crypto crystal. Silivri limestone, which meets the building block requirement of Istanbul and Thrace Region, is a limestone formed by shells, mostly mussel shells. It is a compact rock with light beige, light yellow, dirty white shades, fine-gained and sandy appearance, abundant fossil, hollow, crypto crystal. An important feature is that it is suitable for all kinds of processes when it comes out of nature. After the contact of the stone with air, it takes $\mathrm{CO}_{2}$ into its body and increases its hardness and durability with a secondary hydration.

While there are many analytical studies in the literature on stones, the number of experimental studies on the determination of the technical properties of the building stones is very low. The selection of the most suitable stone in restorations is an important issue by making experimental studies and analyzing the stones with scientific data (CanerSaltık, 1998; Pehlivanoğlu, 2000; Dal, 2008; Dal, 2011; Öcal and Dal, 2012; Dal, 2012; Dal and Öcal, 2013; Erözmen, 2019; Çapar, 2019). In this study, petrogaphic properties, physicomechanical properties, chemical properties and durability properties of stone samples taken from IstanbulSilivri-Akören village quarry have been determined and many tests have been made and their test results have been interpreted in terms of usability in the restoration of historical buildings in Istanbul and Thrace Region.

\section{MATERIAL AND METHOD}

The study area was examined and samples were taken to represent the entire area. Samples were collected from their sources carefully using the cutting tools as coring. It was then placed in polyethylene bags and labeled. Experimental studies were done by TS 699 standard. Petrogaphic, chemical and physicomechanical properties of rocks were determined by using the ITU Mining Faculty Thin Section Workshop, Geochemistry Laboratory and Applied Geology Laboratories.

\section{Usage Areas of Silivri Stone}

Fossil limestone obtained from quarries in Istanbul Bakırköy and Silivri Akören Village during Roman, Byzantine and Ottoman periods has always been the main building material in the works of Mimar Sinan and other Ottoman Architects and distinguished architects of today. It has found a wide range of uses ranging from rough worked to cut stone and densely decorated (Figure 1 and 2).

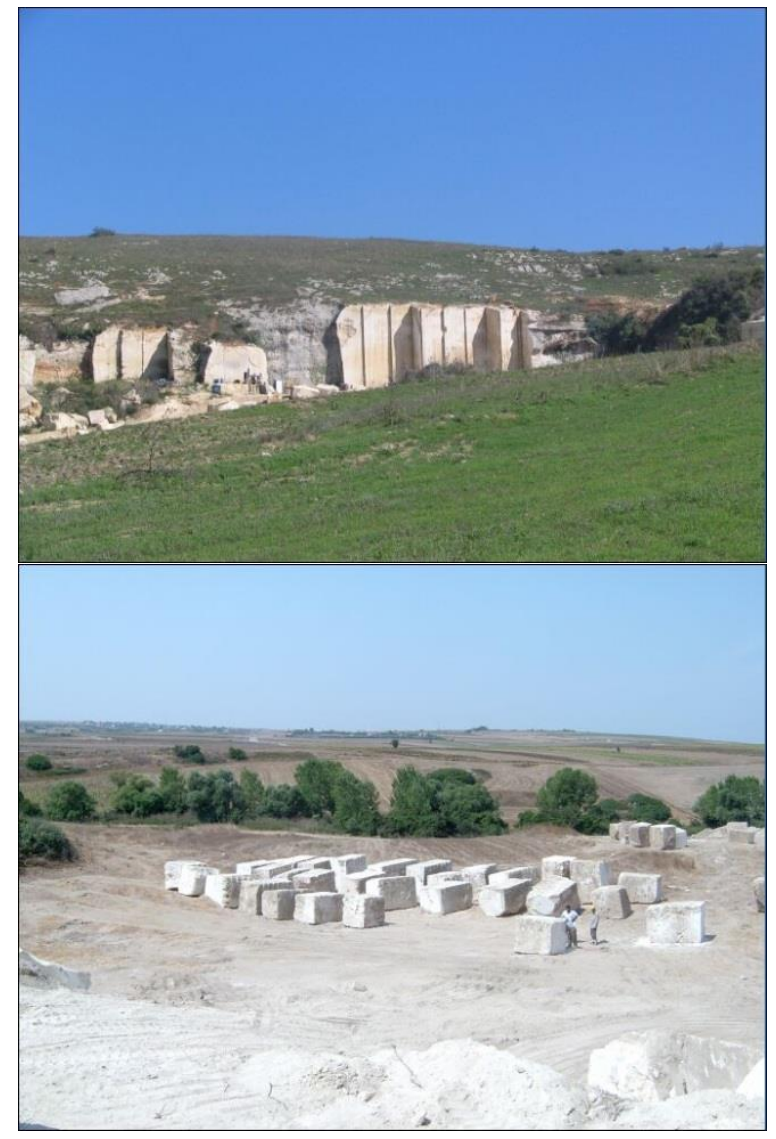

Figure 1. Silivri Akören Village views from limestone quarry

It has been used not only as mesh and exterior material, but also in interiors, floor coverings, arches, warps, jambs, bay windows, fireplaces, reliefs, columns, portals, mihrabs and pulpits. In today's architecture, it is used in building restorations and new buildings, villas, mansions, classical architecture, garden walls, walkways, camellias etc. (Figure 3). 


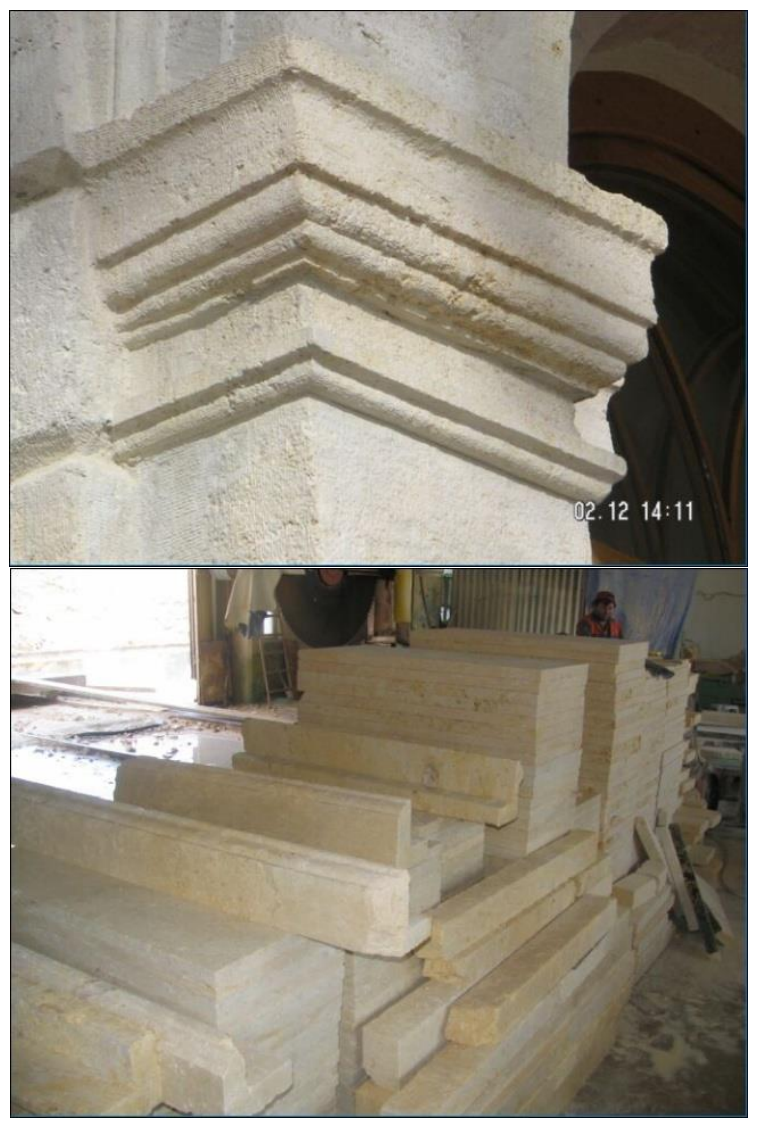

Figure 2. Cut and polished Silivri stone

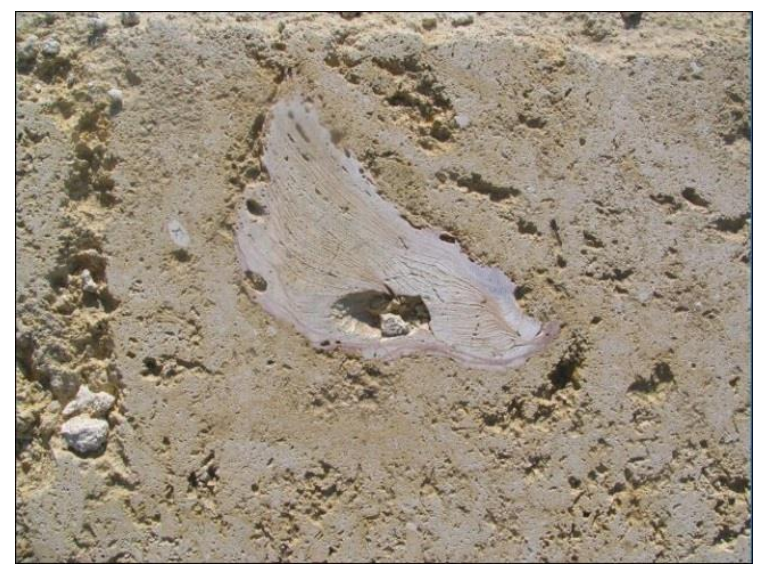

Figure 3. Silivri stone used in restoration works of Dolmabahçe Palace (URL-1, 2000)

\section{Mineralogical and Petrogaphic Properties}

The mineralogical and petrogaphic properties that make up the various internal structures and properties of the stones are important in natural stone characterization. Parameters such as hardness, brittleness, cutability, shape and displacement at the place of use, and being affected by environmental conditions in natural stones are related to the internal structure of the building block. It is important to correctly analyze the physical and mechanical properties of natural stones under different loads, to evaluate natural resources for use in different monuments and to avoid structural problems in the future. By determining these features with mineralogical and petrogaphic analysis methods, it will make it easier to take precautions against the factors that may occur in the place of use of natural stone. The relations of the minerals forming the building block with each other are called tissue. The texture of the stone includes the characteristics of the minerals, size, shape, distribution and orientation of the minerals, as well as information on the different pressure-temperature conditions and geological evolution that the stone has undergone.

The methods described below are used to determine mineralogical and petrogaphic properties.

\section{Macroscopic Examinations}

With the magnifying glass, the texture, minerals, appearance features and the type of the stone are determined from the broken surface. Macro studies cover the examination of color, structure and gain-tissue relationships of core and field samples with the naked eye.

In the macro observations, the color of the rock is yellowish-white, and the fresh surfaces of beige are whitish beige. Shells of $10-12 \mathrm{~cm}$ in size were observed. When the rock is taken from the quarry, it contains a high amount of moisture, but when it is kept under atmospheric conditions, it absorbs $\mathrm{CO}_{2}$ into its body and a part of its cavities is filled with calcium bicarbonate with the rapid carbonation process. while its porosity and water absorption decrease, its strength and unit volume weight increase.

\section{Polarizing Microscope Studies}

The thin section method has been widely used in petrogaphic analysis for many years. This method can be defined as the examination of thin sections prepared by gluing the rock samples up to 20-30 microns by sticking them on a glass slide under a petrogaphic microscope. By polarizing microscope studies, the texture of the stone, the types and sizes of minerals, cement, rusting minerals, the type of minerals forming the stone, their status relative to 
each other, crystal shape, gain homogeneity, whether there is a glassy appearance or not, porosity, slit, cavity, capillary crack, whether there is decomposition and filling can be determined.

To prepare thin sections of the samples, they are first placed in $1.5 \times 3 \times 1 \mathrm{~cm}$ plastic mold boxes. Then, it is saturated with accelerator and hardener with polyester (ESKIM-extra POLYESTER) mixed under vacuum at 0.132 atm pressure. After hardening, the molded samples are taken out of the boxes and cut into $1 \mathrm{~mm}$ slices to be fixed and dropped to $30 \mu \mathrm{m}$ thickness on glass slides. Thin sections of samples are examined using the NIKON AFX-2A optical microscope equipped with a photogaphic attachment.

In Silivri stone thin section samples, Fe-oxide reddish-brown, dark gay colored spaces are generally observed in the cavity edges and sometimes in the segments of fossil shells suitable for decomposition. Some parts have $8-10 \%$ quartz crumbs. No cracks were observed except for a small amount of melting gaps (Figure 4).

Nummulites, mollusk, bryozoer, coral, echinid thorn and plate fragments, Actinocyclina sp., Discocyclina (goup sella), Asterigerina sp. and various benthic foraminifera particles are observed in the structure. Wrapping algae are in the shape of oval, round, prickly and star. They are observed dispersed in sparicalite cement. Their dimensions range from 0.5-3.0 mm (Figure 4).

Table 1. Mineralogy of limestone samples

\begin{tabular}{|c|c|c|}
\hline $\begin{array}{c}\text { Sample } \\
\text { No }\end{array}$ & Minerals & Other Features \\
\hline ST & $\begin{array}{l}\text { Calcite }+ \\
\text { secondary } \\
\text { calcite }+ \\
\text { quartz }+ \\
\text { opaque } \\
\text { minerals }\end{array}$ & $\begin{array}{l}\text { Abundant fossiliferous } \\
\text { limestone }(20-30 \%), \text { slightly } \\
\text { opaque minerals }(1-2 \%) \text {, } \\
\text { calcites are fine-gained and } \\
\text { micritic, fossil sizes range } \\
\text { from } 0.5-3 \mathrm{~mm} \text {. }\end{array}$ \\
\hline
\end{tabular}

\section{X-Ray Studies (XRD)}

$\mathrm{X}$-Rays are applied to determine the numerical properties and identity of the substance crystal. It is used for the identification of molten salt and clay minerals in stones, mineralogical investigation of
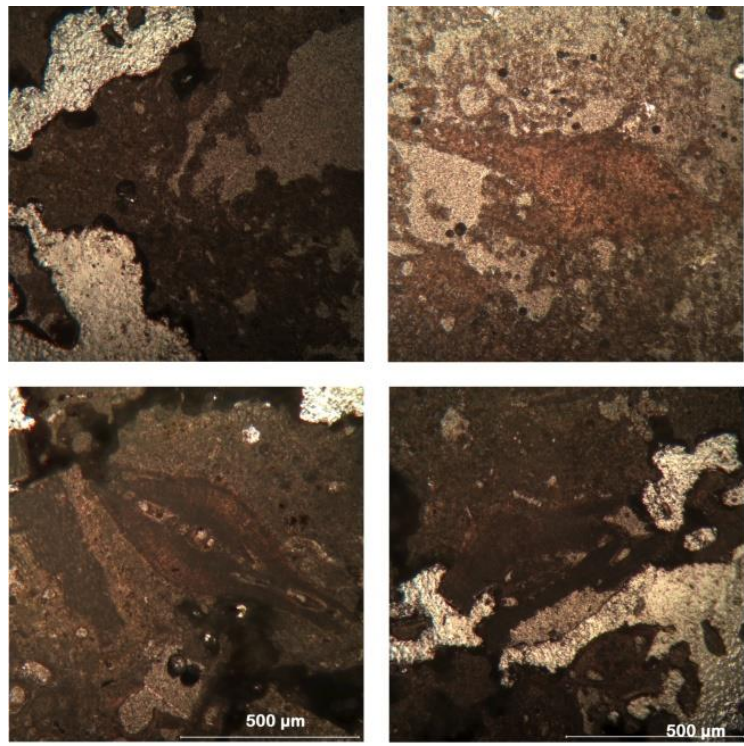

Figure 4. Silivri stone is estimated to be Oligocene (2535 million years ago) due to the presence of Lepidocyolina fossils from carbonated organic limestones. Fossilized, very little oolitic structure is observed, contains micritic limestone, $70-80 \%$ calcite, 20 $30 \%$ fossil and $1-2 \%$ opaque minerals. Microsparitic tissues are observed (Table 1)

rock, blooming products and black dirty crust. First of all, identity is determined at the individual stage with appropriate numerical data and then these numerical features are developed with other suitable methods. XRD analyzes were carried out on powder samples of silivri stone. Before analysis, the outer surfaces, cracked surfaces and relatively inner parts of the samples were gound into fine powders using agate mortar. Samples are first powdered, analyzed under special conditions by X-ray diffractometer (diffractometer), and the goup of each substance is compared within identification standards. The device used is Philips type PWI352/20 X-ray diffractometer. Analyzes were made using the CoKa X-ray with Ni filter set at $35 \mathrm{kV}$ and $14 \mathrm{~mA}$. XRD traces were recorded for $2 \theta$ values from $6^{\circ}$ to $75^{\circ}$. Mineral phases are identified in XRD traces.

In addition to the polarizing microscope, $\mathrm{X}$-rays are also used to determine the mineral compositions of the samples. For this purpose, XRD (X Rays Diffractometer) analysis was performed in two samples. The XRD method is based on the reflection of $X$ rays as they pass through the crystals. This reflection depends on the distance between the atomic plane (in Ao). The rays do not come from the 
first hit, but come in and hit the infinite number of planes parallel to each other and are reflected little by little. The basic principle here is to measure these reflections. For reflections to be measured, reflections mustbe in the same phase. The Equation 1 required for the method is given below.

$$
\mathrm{n}_{\lambda}=2 \mathrm{~d} \cdot \sin \theta
$$

\section{$\lambda$ : Wavelength}

$\mathrm{d}$ : Distance between atoms

$\theta$ : Angle between the crystalline atomic plane and the beam
The mineral composition of silivri stone in $\mathrm{XRD}$ is $95 \%$ calcite-containing limestone (Figure 5).

Table 2. Modal composition of limestones

\begin{tabular}{cc}
\hline \multirow{2}{*}{ Mineral } & Content (\%) \\
\cline { 2 - 2 } & ST \\
\hline Calcite & $90-95$ \\
\hline Secondary calcite & $2-3$ \\
\hline Quartz & $8-10$ \\
\hline Opaque minerals & $1-2$ \\
\hline Clay minerals & - \\
\hline
\end{tabular}

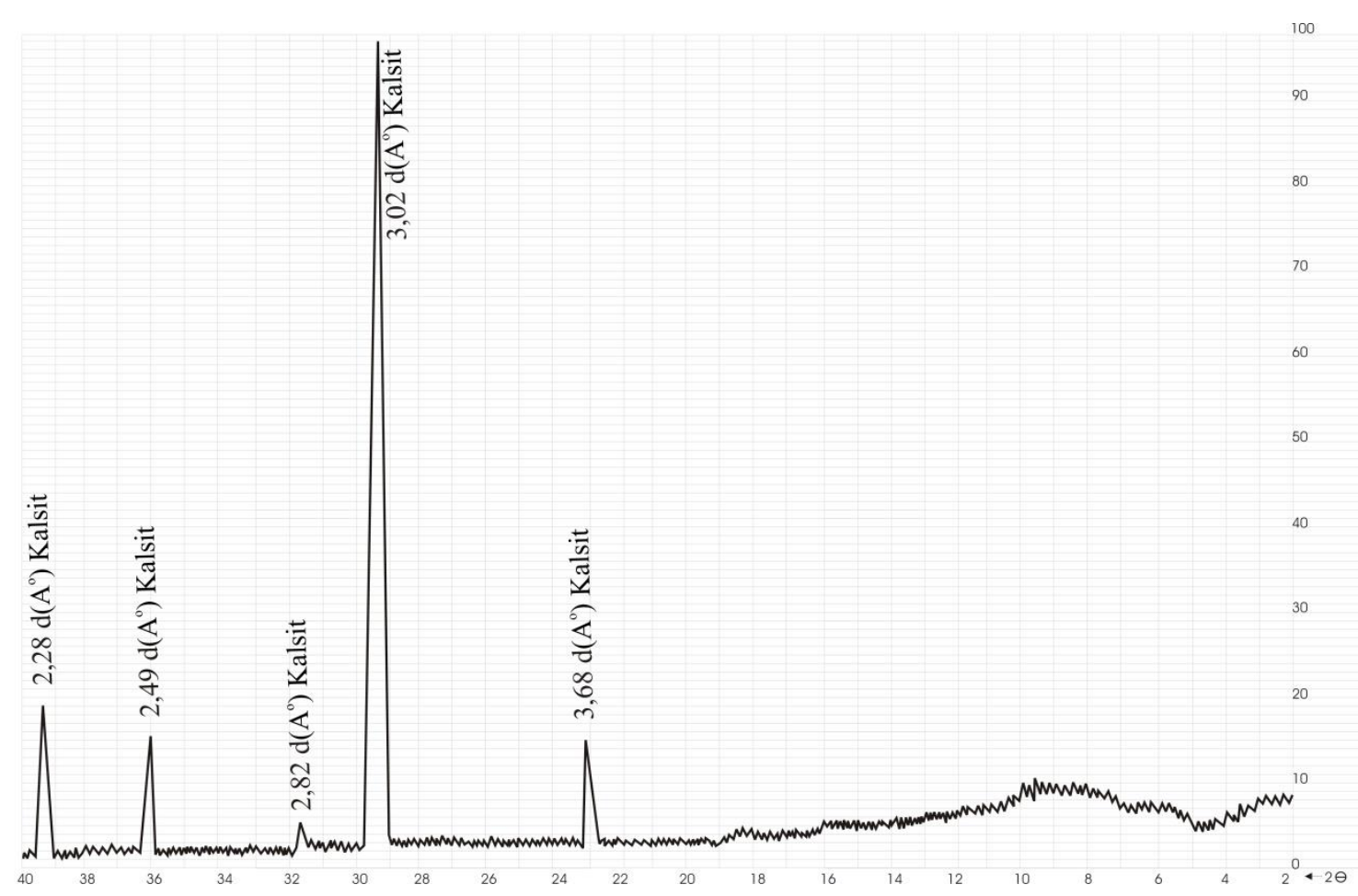

Figure 5. Mineral composition of silivri stone in XRD (limestone containing 95\% calcite)

\section{Scanning Electron Microscope (SEM) Studies}

Scanning electron microscope (SEM) is a type of electron microscope that focuses on the surface and produces images of electron beam and samples (Ponting, 2004). Electrons interact with atoms in the sample to produce various signals and provide information about surface topogaphy and the composition of the sample. Scanning electron microscope accelerates the electrons with $1 \mathrm{kV}-30$ $\mathrm{kV}$. This electron beam is controlled by electromagnetic and electrostatic lenses and focuses on a very small spot. The sample surface is scanned with a focused electron beam. Scanning electron microscopy provides an image of the surface area of the sample (Wang et al., 2005).

Microstructural properties of the carbonates examined in SEM can be directly seen on the screen. Only two-dimensional gains and cavities in the thin section can be examined here in three dimensions. Thus, possible factors that make properties such as porosity and permeability can be interpreted in more 
detail. Chemical analysis can be performed in a short time at a micro-level on the desired gain or spot with the Energy Distributed X-Ray Microanalysis Spectrometer (EDS) that works with SEM. Besides, minerals in the stone types and quantities that cannot be determined by other methods can be detected. Decompositions were observed on the rock surface (Figure 6).
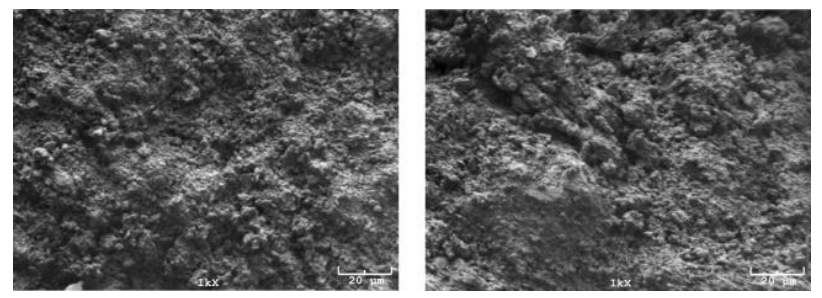

Figure 6. SEM images of Silivri stone (Electron Microscope JEOL JSM T330)

\section{Physical and Mechanical Properties of Silivri Stone}

Tests were carried out to find porosity structure and volume weights, which are among the basic physical properties of silivri stone. In the analysis, each sample was divided into two portions and oven-dried at $45^{\circ} \mathrm{C}$ to constant weight and their dry weights recorded (MDRY). Samples were then immersed in distilled water for 24 hours and left under vacuum in a room at 0.132 atm (100 torr pressure) for approximately 30 minutes to allow water to enter the best pores. Then each sample was removed and its weight was measured by immersing it in the water for Archimedes weight (MARC). All weights were measured with an accuracy of $0.1 \mathrm{mg}$. Calculation of porosity and mass density was done using the following Equations 2 and 3 (Teutonico, 1988; TS 699, 1987);

Total Porosity $=\mathrm{N}=[($ MSAT - MDRY $) /($ MSAT MARC) $] \times 100(\%)$

Mass Density $=\delta=($ MDRY $) /($ MSAT - MARC $)(\mathrm{g}$ $\mathrm{cm}^{-3}$ )

Density $(\delta)$ is the ratio of mass to the actual volume of the sample. Porosity $(\mathrm{N})$ is the fraction of pores or, more simply, the total volume of a porous material, the voids or voids in the mass and is expressed in percent by volume (Teutonico, 1988).
Some physical and mechanical properties of silivri stone are given in Table 1. Dry unit volume weights of Silivri limestones vary between $1.80 \mathrm{~g} \mathrm{~cm}^{-3}$ and $1.89 \mathrm{~g} \mathrm{~cm}^{-3}$.The saturated unit volume weights of Silivri limestones range from $2.09 \mathrm{~g} \mathrm{~cm}^{-3}$ to $2.14 \mathrm{~g}$ $\mathrm{cm}^{-3}$. The pore structure (porosities) of Silivri limestones vary between $25.27 \%$ and $28.88 \%$. These values show that the stone has a very porous structure. The presence of a porous structure is an indication that rainwater and atmospheric chemical substances will enter and allow possible deterioration in the stone.

It is certain that if rainwater enters the pores and the day/night temperature difference ishigh it will seriously damage the stone. When the water freezes, it increases the volume by $9 \%$. Frost pressure occurs. The pressure at the time of the first freezing is around $160 \mathrm{~kg} \mathrm{~cm}^{-2}$, most stones cannot withstand this pressure. For example, the frost pressure at $-13{ }^{\circ} \mathrm{C}$ is around $2000 \mathrm{~kg} \mathrm{~cm}^{-2}$. When the water, which enters between the cracks of the stones, turns from liquid to solid, a force is formed that will break the stones (Schaffer, 1932).

The water absorption amounts of Silivri limestones vary between $13.38 \%$ and $16.04 \%$. The average weight of the dry unit volume of Silivri limestones is $1.85 \mathrm{~g} \mathrm{~cm}^{-3}$. The average of saturated unit volume weights of Silivri limestones is $2.12 \mathrm{~g}$ $\mathrm{cm}^{-3}$. The porosity average of Silivri limestones is $27 \%$. The average water absorption amount of Silivri limestones is $14.65 \%$ (Table 3).

\section{Freezing-Thawing Cycle Experiment}

To measure the durability of a natural stone after frost, TS 699 and TS EN 12371 are tested. First, the core and samples taken from the source of the natural stones are kept in $20^{\circ} \mathrm{C}$ water. The stone samples, which are kept in water for approximately 12 hours, are removed from the water and lowered to $-20{ }^{\circ} \mathrm{C}$ in the freezer 4 hours and kept for 12 hours. Stone samples are then removed from the water and dried at $105{ }^{\circ} \mathrm{C}$. Samples left at room temperature ensure their natural humidity. It is experimented to find the change.

Besides, in the resistance tests of stone samples against frost effect, the losses that occurred in the weight of the samples depending on the time and number of freeze-thaw periods specified in the relevant standard were determined. 5 samples were taken for this study. The decrease in uniaxial 
pressure resistance after this process is an indicator of the resistance against the natural frost effect.

Table 3. Some physical properties of Silivri stone

\begin{tabular}{cccccccc}
\hline $\begin{array}{c}\text { Sampl } \\
\mathbf{e} \\
\mathbf{N o}\end{array}$ & $\begin{array}{c}\text { Dry } \\
\text { weight } \\
(\mathbf{g})\end{array}$ & $\begin{array}{c}\text { Saturated } \\
\text { Weight } \\
(\mathbf{g})\end{array}$ & $\begin{array}{c}\text { Volume } \\
\left(\mathbf{c m}^{\mathbf{3}}\right)\end{array}$ & $\begin{array}{c}\text { Dry unit volume } \\
\text { weight } \\
\left(\mathbf{g ~ c m}^{-\mathbf{3}}\right)\end{array}$ & $\begin{array}{c}\text { Saturated unit } \\
\text { volume weight } \\
\left(\mathbf{g ~ c m}^{-\mathbf{3}}\right)\end{array}$ & $\begin{array}{c}\text { Porosity } \\
(\mathbf{\%})\end{array}$ & $\begin{array}{c}\text { Water } \\
\text { absorption } \\
\text { by weight } \\
(\mathbf{\%})\end{array}$ \\
\hline 1 & 516.61 & 597.27 & 285.73 & 1.81 & 2.09 & 28.23 & 15.61 \\
\hline 2 & 432.05 & 489.85 & 228.71 & 1.89 & 2.14 & 25.27 & 13.38 \\
\hline 3 & 300.98 & 349.27 & 167.20 & 1.80 & 2.09 & 28.88 & 16.04 \\
\hline 4 & 273.05 & 313.45 & 148.39 & 1.84 & 2.11 & 27.23 & 14.80 \\
\hline 5 & 323.58 & 367.04 & 171.15 & 1.89 & 2.14 & 25.39 & 13.43 \\
\hline Medium & & & & $\mathbf{1 . 8 5}$ & $\mathbf{2 . 1 2}$ & $\mathbf{2 7 . 0 0}$ & $\mathbf{1 4 . 6 5}$ \\
\hline
\end{tabular}

Weights were determined before and after frost and the difference was found. During the freezethaw process, no damage was observed to the samples. The average weight losses obtained in the freeze-thaw experiment are $0.53 \%$ (Table 4).

Table 4. Weight loss values of natural stone after natural freeze-thaw

\begin{tabular}{ccccc}
\hline $\begin{array}{c}\text { Sample } \\
\text { no }\end{array}$ & $\begin{array}{c}\text { Weight } \\
\text { before } \\
\text { frost } \\
(\mathbf{g})\end{array}$ & $\begin{array}{c}\text { Weight } \\
\text { after } \\
\text { frost }(\mathbf{g})\end{array}$ & $\begin{array}{c}\text { Weight } \\
\text { loss } \\
\text { after } \\
\text { frost } \\
(\boldsymbol{\%})\end{array}$ & $\begin{array}{c}\text { Average } \\
\text { weight } \\
\text { loss after } \\
\text { frost } \\
(\boldsymbol{\%})\end{array}$ \\
\hline $\mathbf{1}$ & 475.11 & 474.80 & 0.07 & \\
\hline $\mathbf{2}$ & 446.43 & 444.58 & 0.41 & \multirow{2}{*}{0.53} \\
\hline $\mathbf{3}$ & 457.30 & 453.22 & 0.89 & \\
\hline $\mathbf{4}$ & 453.42 & 452.22 & 0.26 & \\
\hline $\mathbf{5}$ & 449.45 & 445.00 & 0.99 & \\
\hline
\end{tabular}

In determining the suitability of natural stones to building materials, uniaxial pressure resistance is an important feature. Single pressure resistance test is done according to ISRM (ISRM, 1981) standards. The dimensions of the cylindrical cores taken must be as follows: length/diameter (L/D) ratio is 2.5-3.0 and $54.7 \mathrm{~mm}$ for NX diameters. Increased pressure is applied to the building stones at certain rates and thestones cannot stand and break at a certain point in the face of the ongoing load. At this point where the break occurs, it gives the maximum load that the stone will bear that force. The upper and lower surfaces of the core samples to be used in the experiment should be parallel and smooth. They should not contain any defects such as cracked fractures. The uniaxial pressure resistance was carried out both on samples that were freeze-thawed and on five samples that were not treated at all (Table 5 and 6). As can be seen from the tables, the average pressure resistance values before and after frost are $105 \mathrm{~kg} \mathrm{~cm}^{-2}$ and $104 \mathrm{~kg} \mathrm{~cm}^{-2}$, respectively.

Table 5. Pressure resistance values of Silivri stone

\begin{tabular}{|c|c|c|c|c|c|}
\hline $\begin{array}{c}\text { Sample } \\
\text { no }\end{array}$ & $\begin{array}{c}\text { Sample } \\
\text { size }(\mathrm{cm})\end{array}$ & $\begin{array}{c}\text { Sample } \\
\text { diameter } \\
(\mathrm{cm})\end{array}$ & $\begin{array}{l}\text { Breaking } \\
\text { load }(\mathbf{k g})\end{array}$ & $\begin{array}{c}\text { Pressure } \\
\text { resistance } \\
\left(\mathrm{kg} \mathrm{cm}^{-2}\right)\end{array}$ & $\begin{array}{c}\text { Average } \\
\text { pressure } \\
\text { resistance } \\
\left(\mathrm{kg} \mathrm{cm}^{-2}\right)\end{array}$ \\
\hline 1 & 10.91 & 5.4 & 2600 & 113 & \multirow{5}{*}{105} \\
\hline 2 & 10.93 & 5.4 & 3750 & 163 & \\
\hline 3 & 10.97 & 5.4 & 2100 & 91 & \\
\hline 4 & 10.91 & 5.4 & 1800 & 78 & \\
\hline 5 & 10.94 & 5.4 & 1800 & 78 & \\
\hline
\end{tabular}


Table 6. Pressure resistance values of Silivri stone after freeze-thaw

\begin{tabular}{cccccc}
\hline $\begin{array}{c}\text { Sample } \\
\text { no }\end{array}$ & $\begin{array}{c}\text { Sample size } \\
(\mathbf{c m})\end{array}$ & $\begin{array}{c}\text { Sample } \\
\text { diameter }(\mathbf{c m})\end{array}$ & $\begin{array}{c}\text { Breaking load } \\
\mathbf{( k g )}\end{array}$ & $\begin{array}{c}\text { Pressure resistance } \\
\left(\mathbf{k g ~ c m}^{-2}\right)\end{array}$ & $\begin{array}{c}\text { Average pressure } \\
\text { resistance } \\
\left(\mathbf{k g ~ c m}^{-2}\right)\end{array}$ \\
\hline $\mathbf{1}$ & 10.87 & 5.4 & 4200 & 183 & \\
\hline $\mathbf{2}$ & 10.87 & 5.4 & 1650 & 72 & 104 \\
\hline $\mathbf{3}$ & 10.85 & 5.4 & 1850 & 81 & \\
\hline $\mathbf{4}$ & 10.85 & 5.4 & 1300 & 57 & \\
\hline $\mathbf{5}$ & 10.86 & 5.4 & 2900 & 127 & \\
\hline
\end{tabular}

\section{Chemical Properties of Silivri Stone}

In chemical analysis of Silivri limestones, most of the rock constitutes $\mathrm{CaO}$ with an average of $51.20 \%$. It contains elements with ratios of $31.50 \%$ LOI, $19.91 \% \quad \mathrm{SiO}_{2} \quad 1.32 \% \quad \mathrm{Al}_{2} \mathrm{O}_{2}, 0.51 \% \quad \mathrm{Fe}_{2} \mathrm{O}_{2}$, $0.48 \% \mathrm{MgO}, 0.28 \% \mathrm{~K}_{2} \mathrm{O}, 0.10 \% \mathrm{Na}_{2} \mathrm{O}$. According to these values, Silivri stone is limestone with high silica content (Table 7).

Table 7. Geochemical analysis values of Silivri stone

\begin{tabular}{|c|c|c|c|c|c|c|c|}
\hline $\begin{array}{c}\mathrm{SiO}_{2} \\
(\%)\end{array}$ & $\begin{array}{c}\mathbf{A l}_{2} \mathbf{O}_{2} \\
(\%) \\
\end{array}$ & $\begin{array}{c}\mathrm{Fe}_{2} \mathrm{O}_{2} \\
(\%) \\
\end{array}$ & $\begin{array}{c}\mathrm{CaO} \\
(\%) \\
\end{array}$ & $\begin{array}{c}\text { MgO } \\
(\%)\end{array}$ & $\begin{array}{c}\mathrm{Na}_{2} \mathrm{O} \\
(\%)\end{array}$ & $\begin{array}{r}\mathrm{K}_{2} \mathrm{O} \\
(\%) \\
\end{array}$ & $\begin{array}{l}\text { LOI } \\
(\%)\end{array}$ \\
\hline 19.91 & 1.32 & 0.51 & 51.20 & 0.48 & 0.10 & 0.28 & 31.5 \\
\hline
\end{tabular}

\section{RESULTS AND DISCUSSION}

Silivri stone is produced from the quarries around Akören Village. It is a compact rock with light beige, light yellow, dirty white shades, fine gained and sandy appearance, abundant fossil, hollow, crypto crystal. When it is kept under atmospheric conditions, by taking $\mathrm{CO}_{2}$ into its body, a part of its cavities is filled with calcium bicarbonate and its strength increases with the rapid carbonation process.

In the thin sections of silivri stone, $70-80 \%$ calcite, $20-30 \%$ fossil, $1-2 \%$ opaque mineral were observed. Microsparitic tissues are observed. Nummulites, mollusk, bryozoer, coral, echinid thorn and plate fragments, Actinocyclina sp., Discocyclina (goup sella), Asterigerina sp., Various benthic foraminifera particles and wrapper oval, round, prickly, star algae are scattered in spar calcite cement. Its dimensions range from 0.5-3.0 $\mathrm{mm}$. The mineral composition in XRD is limestone containing 95\% calcite. In SEM studies, it has been observed that the rock has a micritic structure and weathering. Some physical and mechanical properties (Table 1, $2,3,4)$ of Silivri stone determined according to TS 699 are given. According to the results of chemical analysis, it is limestone with high silica content. In addition to these analyzes, the chemical test in the Silivri stones can be revealed with the spot test that can be done in the future, and as a result, the physical and chemical changes in the monuments used as building materials can give an idea. The chemical effect of rainwater and temperature differences can be revealed more widely. The use of silivri stones in historical buildings and the analysis of the physical/chemical deterioration in these buildings is a separate study. This article will be a source for comparing the results of such studies or for supporting such studies. According to the results of the analysis, Bakırköy kufeki stones can be used instead of kufek since they conform with the technical specifications and building blocks usage standard.

\section{REFERENCES}

Caner-Saltık, E.N., 1998. Diagnosis of deterioration in exposed stone for the purpose of conservation. The First Regional Course on Conservation of Stone in Central and Western Asia, April 9-23.

Çapar, E.M., 2019. Bazı küfeki taşlarının fiziksel ve mekanik özelliklerinin karşılaştırmalı olarak incelenmesi. Yüksek Lisans Tezi, İTÜ Fen Bilimleri Enstitüsü, İstanbul.

Dal, M., 2008. Kırklareli (Vize-Pınarhisar) Bölgesi kalkerlerinin restorasyonda kullanılabilirliği. Doktora Tezi, Trakya Üniversitesi Fen Bilimleri Enstitüsü, Edirne.

Dal, M., 2011. Salts deterioration effects in P1narhisar limestone and Marmara white marbles. Trakya University Gaduate School of Natural and Applied Journal Sciences, 12(1): 47-56.

Dal, M., 2012. Clay minerals and their effects at stones of Edirne historic building. Trakya University Journal of Engineering Sciences, 13(1):31-39.

Dal, M., Öcal, A.D., 2013. Investigations on stone weathering of Ottoman Architecture: A Kirklareli Hizırbey Kulliye case study. PARIPEX Indian Journal of Research, 2:11. 
Erözmen, T., 2019. Tarihi eserlerde kullanılan küfeki taşlarının litolojik özellikleri ve temizleme yöntemleri karşısındaki davranışları. Yüksek Lisans Tezi, İstanbul Üniversitesi Fen Bilimleri Enstitüsü, İstanbul.

Fitzner, B., Heinrichs K., 2004. Photo atlas of weathering forms on stone monuments. www.stone.rwth-aachen.de. 20 January 2020.

ISRM, 1981. Rock Caharacterization, testing and monitoring: ISRM suggested methods. E.T. Brown (ed.), Pergamon Press, 178-184.

Öcal, A.D., Dal, M., 2012. Deterioration on natural stones. Architectural Foundation, Financial Business Publications, İstanbul.

Pehlivanoğlu, C.R., 2000. Kirklareli-Pınarhisar dolaylarının malzeme jeolojisi ve kireçtaşlarının tarihi eserlerde kullanılabilirliğinin araştırılması, Yüksek Lisans Tezi, İTÜ Fen Bilimleri Enstitüsü, İstanbul.

Ponting, M., 2004. The scanning electron microscope and the archaeologist. Physics Education, 39(2):166170.

Schaffer, R.J., 1932. The weathering of natural building stones, Building Research, 18.

Smith B.J., Turkington A.V., 2004. Stone decay: its causes and controls: proceedings of weathering 2000. An International Symposium Held in Belfast 26-30 June 2000, Donhead Publishing Limited.

Teutonico, J.M., 1988. A laboratory manual for architectural conservators. ICCROOM, Rome, 32122.

TS 699, 1987. Standard test methods for natural stones, Turkish Standard.

URL-1， 2000. http://www.atlasmadencilik.com, 12 January 2020.

Wang, A.-Q., Liu, J.-H., Lin, S.D., Lin, T.-S., Mou C.Y. 2005. A novel efficient Au-Ag alloy catalyst system: Preparation, activity, and characterization. Journal of Catalysis, 233(1):186-197.

Woolfitt, C., 2000. Soluble salts in masonry. The building conservation directory, London. 